\title{
The Relationship between Age, Parity, Early Detection, K1-K4 Visits, Integrated ANC, Three Times Obgyn's Ultrasound Examination, and Maternal Mortality
}

\author{
Milhan $^{1}$, Indang Trihandini ${ }^{2}$, Shinta Prawitasari ${ }^{3}$ \\ ${ }^{1}$ Doctoral Program of Faculty of Public Health, Universitas Indonesia \\ ${ }^{2}$ Lecturer, Faculty of Public Health, Universitas Indonesia \\ ${ }^{3}$ Lecturer, Department of Obstetrics and Gynecology, Faculty of Medicine, Public Health and Nursing, \\ Gadjah Mada University, Indonesia \\ Corresponding Author: Milhan
}

DOI: https://doi.org/10.52403/ijrr.20220138

\begin{abstract}
Maternal mortality is one of the indicators of health-care quality and effectiveness. Maternal mortality increases and decreases due to several factors. This article aims to analyze the factors that cause the increase and decrease in the maternal mortality rate. The research method is a cohort prospective, using a systematic sampling technique with the principle of proportionality. The number of samples is $\mathbf{1 5 0}$ data taken from the Tapin District Health Office, South Kalimantan, Indonesia. Statistical data analysis was performed using statistical descriptions and statistical inferential. The results of hypothesis testing indicate that age, early detection, $\mathrm{K} 1$ - K4 visits, integrated ANC and $3 \mathrm{x}$ SpOG ultrasound have a significant effect on maternal mortality. The parity does not have a significant effect on maternal mortality. Therefore, the pregnancy program must pay attention to age. During pregnancy, pregnant women must go through the process of early detection, K1 - K4 visits, integrated ANC. Parity must be considered so that babies can be born with conditions without deficiencies.
\end{abstract}

Keywords: Age; Parity; Early Detection; K1 K4 Visits; ANC, Ultrasound; Maternal Mortality

\section{INTRODUCTION}

Maternal mortality is one of the indicators of health-care quality and effectiveness (MacDorman et al., 2018; Setiawan \& Nurcahyanto, 2020). Maternal Mortality Rate is currently still significantly below the Sustainable Development Goals (SDGs) target of 70 per 100,000 live births by 2030 (Callister \& Edwards, 2017). In developed and developing countries, 15-20 percent of pregnant women are at high risk (Suarayasa, 2020).

In Indonesia, there is a positive trend of decreasing maternal mortality from 1991 to 2020 , which is 390 to 230 per 100,000 with an average decrease of $1.8 \%$ per year. Despite the decline, the maternal mortality rate has not yet reached the MDGs target for 2015 and the upcoming SDGs for 2030 (Kemenkes, 2019).This is completely illustrated in Figure 1 below (Prabhakara, 2010).

There are increases and decreases in maternal mortality due to several factors. In SGDs there is a decrease but still not beyond the target number. Therefore, this article aims to analyze the factors that cause the increase and decrease in the maternal mortality rate.

Age is one of the factors that need to be considered to maintain the stability of the 
mother's pregnancy process (Nove et al., 2014). Apart from age, parity also has an impact on maternal mortality (HuayanayEspinoza et al., 2017). Early detection with a clear protocol is needed to prevent maternal mortality and can be a good prenatal (Ghulmiyyah \& Sibai, 2012). Good antenatal care can reduce antepartum mortality rates (Merdad \& Ali, 2018), in Indonesia carried out with $\mathrm{K} 1$ - K4 visits. Visits 4 times for pregnant women is one of the public health efforts to meet the SDGs target (Ghosh \& Ghosh, 2020). Diagnostic ultrasound also has an important role in pregnancy management to prevent maternal death (Thurber \& Fleischer, 2019).

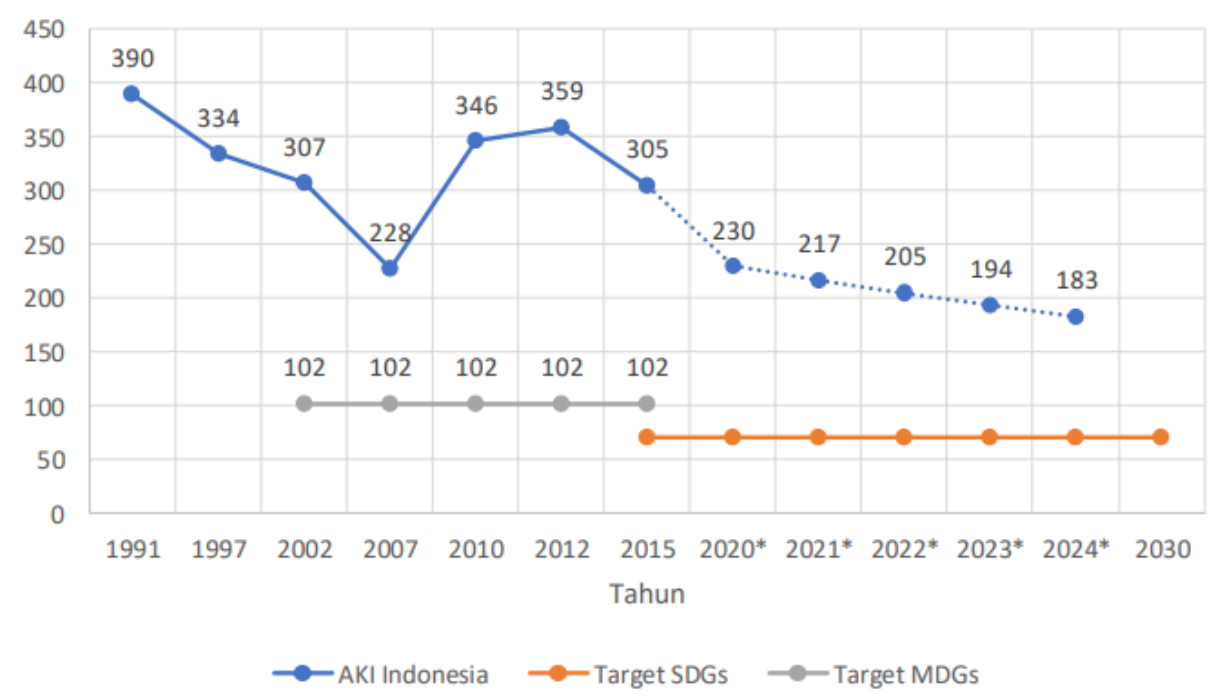

Figure 1.The development of maternal mortality in MDGs and SDGs

\section{MATERIAL AND METHODS}

The research method is a cohort prospective, using a systematic sampling technique with the principle of proportionality, then correlation test. Data taken from the Tapin District Health Office, South Kalimantan, Indonesia. The data sample is data for a period of 12 months (January - December 2016) at the Data Sanggul Hospital, South Kalimantan, Indonesia.

The number of samples is 150 data with a sample selection technique by systematic sampling. The independent variables were age, parity, early detection, $\mathrm{K} 1$ - K4 visits, integrated $\mathrm{ANC}$ and $3 \mathrm{x}$ SpOG Ultrasound. The dependent variable is the maternal mortality rate.

Statistical data analysis was performed using statistical descriptions and normality tests. The Pearson correlation test is used if the distribution is normal, while the Spearman correlation test is used if it is not.

\section{Hypothesis}

H1: The age has a significant influence on the maternal mortality.

$\mathrm{H} 2$ : The parity has a significant influence on the maternal mortality.

H3: The early detection has a significant influence on the maternal mortality.

H4: The K1 - K4 visits has a significant influence on the maternal mortality.

H5: The integrated ANC has a significant influence on the maternal mortality.

H6: The 3x SpOG Ultrasound has a significant influence on the maternal mortality

\section{RESULTS}

From the results of data processing, statistically descriptive obtained the classification of age, parity, early detection, $\mathrm{K} 1$ - K4 visits, integrated ANC, 3x SpOG Ultrasound and maternal mortality. Table 1 below is a descriptive statistic for each variable. 
Milhan et.al. The relationship between age, parity, early detection, K1-K4 visits, integrated ANC, three times Obgyn's ultrasound examination, and maternal mortality.

Table 1. The frequency of each variable

\begin{tabular}{|l|l|l|}
\hline \multicolumn{3}{|c|}{ Table 1. The frequency of each variable } \\
\hline Variable & Frequency & Percentage \\
\hline Age classification & & \\
\hline Less than 20 years old & 16 & 10.70 \\
\hline $20-29$ & 66 & 44.00 \\
\hline $30-39$ & 61 & 40.70 \\
\hline 40 years old and above & 7 & 4.40 \\
\hline Parity classification & & \\
\hline Parity 1 & 38 & 25.30 \\
\hline Parity 2 & 65 & 43.30 \\
\hline Parity 3 & 31 & 20.70 \\
\hline Parity 4 & 15 & 10.00 \\
\hline Parity 5 & 1 & 0.70 \\
\hline Early detection & & \\
\hline No & 12 & 8.00 \\
\hline Yes & 138 & 92.00 \\
\hline K1 - K4 visits & & \\
\hline K1 & 12 & 8.00 \\
\hline K2 & 56 & 37.30 \\
\hline K3 & 58 & 38.70 \\
\hline K4 & 24 & 16.80 \\
\hline Integrated ANC & & \\
\hline No & 17 & 11.30 \\
\hline Yes & 133 & 88.70 \\
\hline 3x SpOG Ultrasound & & \\
\hline No & 33 & 78.00 \\
\hline Yes & 117 & 98.70 \\
\hline Maternal mortality & & \\
\hline Died & 2 & \\
\hline Not Died & 148 & \\
\hline & & \\
\hline & & \\
\hline & & \\
\hline
\end{tabular}

Statistically inferential, table 2 below is a test of data assumptions using the normality test.

Table 2. Kolmogorov Smirnov Test

\begin{tabular}{|l|l|l|} 
Table 2. Kolmogorov Smirnov Test \\
\begin{tabular}{|l|l|l|}
\hline Variable & Sig. & Result \\
\hline Age classification & 0.019 & No \\
\hline Parity classification & 0.000 & No \\
\hline Early detection & 0.000 & No \\
\hline K1 - K4 visits & 0.000 & No \\
\hline Integrated ANC & 0.000 & No \\
\hline 3x SpOG Ultrasound & 0.000 & No \\
\hline Maternal mortality & 0.000 & No \\
\hline
\end{tabular}
\end{tabular}

Based on the table above, all variables show the value of sig. less than 0.05 , it means that all the variables show that the data is not normally distributed. Because, the distribution is not normal, the data is transformed, but the results are still not normal distribution, then Spearman test with SPSS is performed to test the hypothesis.

\begin{tabular}{|c|c|c|c|c|}
\hline $\begin{array}{l}\text { Independent } \\
\text { Variable }\end{array}$ & Dependent variable & $\mathbf{P}$ & $\mathbf{H}$ & Support \\
\hline $\begin{array}{l}\text { Age } \\
\text { classification }\end{array}$ & Maternal mortality & 0.018 & 1 & Yes \\
\hline $\begin{array}{l}\text { Parity } \\
\text { classification }\end{array}$ & Maternal mortality & 0.296 & 2 & No \\
\hline Early detection & Maternal mortality & 0.000 & 3 & Yes \\
\hline $\mathrm{K} 1-\mathrm{K} 4$ visits & Maternal mortality & 0.016 & 4 & Yes \\
\hline $\begin{array}{l}\text { Integrated } \\
\text { ANC }\end{array}$ & Maternal mortality & 0.000 & 5 & Yes \\
\hline $\begin{array}{l}3 \mathrm{x} \text { SpOG } \\
\text { Ultrasound }\end{array}$ & Maternal mortality & 0.007 & 6 & Yes \\
\hline
\end{tabular}

\section{DISCUSSION \\ Relation Between Age And Maternal Mortality}

The results of hypothesis testing indicate that the age has a significant influence on the maternal mortality. Age is one of the factors that need to be considered to maintain the stability of the mother's pregnancy process (Nove et al., 2014). In addition, the age at birth is an important factor for the welfare of mothers and children after the birth process (Assari et al., 2019).

The mother's age at childbearing has changed dramatically in recent decades due to a variety of cultural and social determinants. Reproductive age is considered to be at risk for an adverse outcome (Londero et al., 2019).

High age has a risk of pregnancy (Morris et al., 2018).Maternal age when pregnant biologically has an emotional, mental and nutritional fulfillment during pregnancy (Rangkuti \& Harahap, 2020).

\section{Relation Between Parity and Maternal Mortality}

Parity was defined as the number of children ever born to a woman(HuayanayEspinoza et al., 2017). The results of hypothesis testing indicate that parity does not have a significant effect on maternal mortality. Even though it has no significant effect, women with high parity should pay attention to the negative impact that arises. Based on the perception of high parity women, the problem that arises is the problem of their welfare and quality of life (Alzboon \& Vural, 2021).

Few cases of death are caused by parity. However, parity can affect placental weight during pregnancy (Flatley et al., 2021). The placenta supplies nutrients and oxygen to the fetus. Therefore, parity must be considered so that babies can be born with conditions without deficiencies. Moreover, parity has a high risk of maternal cardiovascular disease and has the potential to cause type 2 diabetes mellitus(Klingberg et al., 2017). 


\section{Relation Between Early Detection and Maternal Mortality}

The results of hypothesis testing indicate that the early detection has a significant influence on the maternal mortality. One of the challenges in the effort to conduct early pregnancy detection is that several health facilities are not sufficient. The availability of essential facilities and medicines increases the risk of maternal morbidity and mortality(Ansari et al., 2019).

Through early detection, it is possible to anticipate the incidence of hypertension in pregnant women. Early detection is done by hemodynamic screening for circulatory disorders, to improve maternal-fetal outcomes, it can be done by selecting the right intervention(Phillips et al., 2020).In addition, early detection is very important for pregnant women who are at risk of preeclampsia in the first trimester (Mönckeberg et al., 2020).

\section{Relation Between K1 - K4 visits and Maternal Mortality}

The results of hypothesis testing indicate that the $\mathrm{K} 1-\mathrm{K} 4$ visits has a significant influence on the maternal mortality. To prevent maternal mortality, the government must pay attention to the procedures for antenatal care until delivery (Purhadi et al., 2021). In Indonesia, the k1$\mathrm{k} 4$ examination is highly recommended by the government. The $\mathrm{k} 1-\mathrm{k} 4$ examination is that pregnant women carry out routine checks at least four times. At least once in the first trimester, at least once in the second trimester and at least 2 times in the third trimester. Continuing care for pregnant women can reduce maternal mortality (Merdad \& Ali, 2018).

\section{Relation Between Integrated ANC and Maternal Mortality}

An effective strategy to reduce the risk of maternal and neonatal mortality is the integration of ANC(Hirai et al., 2020; Palmer et al., 2021). The results of hypothesis testing indicate that the integrated ANC has a significant influence on the maternal mortality. Therefore, the solution that can be done is to improve the quality of ANC services (Ejigu Tafere et al., 2018).

However, various difficulties were discovered and classified during the implementation of integrated ANC, including strategy, care process, administration and management support (Afrizal et al., 2020). Diseases in pregnant women can be detected and integrated early with Antenatal Care services that must be carried out in a comprehensive, integrated and quality manner. Pregnant women should also get more comprehensive and integrated services, missed opportunities can be avoided and services can be carried out more effectively and efficiently.

\section{Relation Between 3x SpOG ultrasound and Maternal Mortality}

Routine ultrasound can help reduce perinatal mortality and prevent maternal mortality(Goldenberg et al., 2018). The results of hypothesis testing indicate that the $3 \mathrm{x}$ SpOG Ultrasound has a significant influence on the maternal mortality. In some countries, the use of ultrasound has proven that ultrasound can detect pregnancies that have a high risk of death. Therefore, it is necessary to train for quality ultrasound examinations and improve doctor services (Holmlund et al., 2018).

The inside of a pregnant woman's uterus can be seen using ultrasound. It can help doctors in analyzing a pregnancy. In addition, it can see the presence or absence of an embryo, ultrasound can also be used to determine estimated labor, gestational age, weight and length of the fetus.

\section{CONCLUSIONS}

Age, early detection, $\mathrm{K} 1-\mathrm{K} 4$ visits, integrated $\mathrm{ANC}$ and 3x SpOG Ultrasound have a significant effect on maternal mortality. The parity does not have a significant effect on maternal mortality. High age has a risk of pregnancy. Early detection is very important to control the 
fetus and the risk of maternal mortality. Continuing $\mathrm{K} 1-\mathrm{K} 4$ visits can reduce maternal mortality. An effective strategy to reduce the risk of maternal and neonatal mortality is the integration of ANC. Routine ultrasound can help reduce perinatal mortality and prevent maternal mortality. Women with high parity should pay attention to the negative impact that arises. Parity can affect placental weight during pregnancy.

\section{Acknowledgement: None}

\section{Conflict of Interest: None}

\section{Source of Funding: None}

\section{Ethical Approval: Approved}

\section{REFERENCES}

1. Afrizal, S. H., Hidayanto, A. N., Handayani, P. W., Besral, B., Martha, E., Markam, H., Budiharsana, M., \& Eryando, T. (2020). Evaluation of integrated antenatal care implementation in primary health care. Journal of Integrated Care, 28(2), 99-117. https://doi.org/10.1108/JICA-07-2019-0031

2. Alzboon, G., \& Vural, G. (2021). The Experience of Healthy Pregnancy in High Parity Women: A Phenomenological Study in North Jordan. Medicina, 57(8), 853. https://doi.org/10.3390/medicina57080853

3. Ansari, N., Manalai, P., Maruf, F., Currie, S., Stekelenburg, J., van Roosmalen, J., Kim, Y.-M., \& Tappis, H. (2019). Quality of care in early detection and management of pre-eclampsia/eclampsia in health facilities in Afghanistan. BMC Pregnancy and Childbirth, 19(1), 36. https://doi.org/10.1186/s12884-018-2143-0

4. Assari, S., Mardani, A., Maleki, M., \& Bazargan, M. (2019). Black-White Differences in the Association between Maternal Age at Childbirth and Income. Women's Health Bulletin, 6(4), 36-42. https://doi.org/10.30476/whb.2019.46236

5. Callister, L. C., \& Edwards, J. E. (2017). Sustainable Development Goals and the Ongoing Process of Reducing Maternal Mortality. Journal of Obstetric, Gynecologic \& Neonatal Nursing, 46(3), e56-e64. https://doi.org/https://doi.org/10.1016/j.jogn .2016.10.009

6. Ejigu Tafere, T., Afework, M. F., \& Yalew, A. W. (2018). Antenatal care service quality increases the odds of utilizing institutional delivery in Bahir Dar city administration, North Western Ethiopia: A prospective follow up study. PLOS ONE, 13(2), e0192428.

https://doi.org/10.1371/journal.pone.019242 8

7. Flatley, C., Sole-Navais, P., Vaudel, M., Helgeland, Ø., Modzelewska, D., Johansson, S., Jacobsson, B., \& Njølstad, P. (2021). Placental weight centiles adjusted for age, parity and fetal sex. Placenta. https://doi.org/10.1016/j.placenta.2021.10.0 11

8. Ghosh, A., \& Ghosh, R. (2020). Maternal health care in India: A reflection of 10 years of National Health Mission on the Indian maternal health scenario. Sexual \& Reproductive Healthcare, 25, 100530. https://doi.org/10.1016/j.srhc.2020.100530

9. Ghulmiyyah, L., \& Sibai, B. (2012). Maternal Mortality From Preeclampsia/Eclampsia. Seminars in Perinatology, 36(1), 56-59. https://doi.org/https://doi.org/10.1053/j.sem peri.2011.09.011

10. Goldenberg, R., Nathan, R., Swanson, D., Saleem, S., Mirza, W., Esamai, F., Muyodi, D., Garces, A., Figueroa, L., Chomba, E., Chiwala, M., Mwenechanya, M., Tshefu, A., Lokangako, A., Bolamba, V., Moore, J., Franklin, H., Swanson, J., Liechty, E., ... McClure, E. (2018). Routine antenatal ultrasound in low- and middle-income countries: first look - a cluster randomised trial. BJOG: An International Journal of Obstetrics \& Gynaecology, 125(12), 1591$1599 . \quad$ https://doi.org/10.1111/14710528.15287

11. Hirai, M., Morris, J., Luoto, J., Ouda, R., Atieno, N., \& Quick, R. (2020). The impact of supply-side and demand-side interventions on use of antenatal and maternal services in western Kenya: a qualitative study. BMC Pregnancy and Childbirth, 20(1), 453. https://doi.org/10.1186/s12884-020-03130-4

12. Holmlund, S., Ntaganira, J., Edvardsson, K., Lan, P. T., Semasaka Sengoma, J. P., Lesio Kidanto, H., Ngarina, M., Small, R., \& Mogren, I. (2018). Health professionals' 
experiences and views on obstetric ultrasound in Rwanda: A cross-sectional study. PLOS ONE, 13(12), e0208387. https://doi.org/10.1371/journal.pone.020838 7

13. Huayanay-Espinoza, C. A., Quispe, R., Poterico, J. A., Carrillo-Larco, R. M., BazoAlvarez, J. C., \& Miranda, J. J. (2017). Parity and Overweight/Obesity in Peruvian Women. Preventing Chronic Disease, 14, 160282.

https://doi.org/10.5888/pcd14.160282

14. Kemenkes. (2019). Dak Fisik Bidang Kesehatan Dalam Mendukung Target Penurunan Angka Kematian Ibu Dan Anak. Angewandte Chemie International Edition, 6(11), 951-952., 3(2), 1.

15. Klingberg, S., Brekke, H. K., Winkvist, A., Engström, G., Hedblad, B., \& Drake, I. (2017). Parity, weight change, and maternal risk of cardiovascular events. American Journal of Obstetrics and Gynecology, 216(2), 172.e1-172.e15. https://doi.org/10.1016/j.ajog.2016.09.105

16. Londero, A. P., Rossetti, E., Pittini, C., Cagnacci, A., \& Driul, L. (2019). Maternal age and the risk of adverse pregnancy outcomes: a retrospective cohort study. BMC Pregnancy and Childbirth, 19(1), 261. https://doi.org/10.1186/s12884-019-2400-x

17. MacDorman, M. F., Declercq, E., \& Thoma, M. E. (2018). Trends in Texas maternal mortality by maternal age, race/ethnicity, and cause of death, 2006-2015. Birth, 45(2), 169-177. https://doi.org/10.1111/birt.12330

18. Merdad, L., \& Ali, M. M. (2018). Timing of maternal death: Levels, trends, and ecological correlates using sibling data from 34 sub-Saharan African countries. PLOS ONE, 13(1), e0189416. https://doi.org/10.1371/journal.pone.018941 6

19. Mönckeberg, M., Arias, V., Fuenzalida, R., Álvarez, S., Toro, V., Calvo, A., Kusanovic, J. P., Monteiro, L. J., Schepeler, M., Nien, J. K., Martinez, J., \& Illanes, S. E. (2020). Diagnostic Performance of First Trimester Screening of Preeclampsia Based on Uterine Artery Pulsatility Index and Maternal Risk Factors in Routine Clinical Use. Diagnostics, $\quad 10(4), \quad 182$. https://doi.org/10.3390/diagnostics 1004018 2

20. Morris, J. M., Totterdell, J., Bin, Y. S., Ford, J. B., \& Roberts, C. L. (2018).
Contribution of maternal age, medical and obstetric history to maternal and perinatal morbidity/mortality for women aged 35 or older. Australian and New Zealand Journal of Obstetrics and Gynaecology, 58(1), 9197. https://doi.org/10.1111/ajo.12674

21. Nove, A., Matthews, Z., Neal, S., \& Camacho, A. V. (2014). Maternal mortality in adolescents compared with women of other ages: evidence from 144 countries. The Lancet Global Health, 2(3), e155-e164. https://doi.org/https://doi.org/10.1016/S221 4-109X(13)70179-7

22. Palmer, K. R., Tanner, M., Davies-Tuck, M., Rindt, A., Papacostas, K., Giles, M. L., Brown, K., Diamandis, H., Fradkin, R., Stewart, A. E., Rolnik, D. L., Stripp, A., Wallace, E. M., Mol, B. W., \& Hodges, R. J. (2021). Widespread implementation of a low-cost telehealth service in the delivery of antenatal care during the COVID-19 pandemic: an interrupted time-series analysis. The Lancet, 398(10294), 41-52. https://doi.org/10.1016/S01406736(21)00668-1

23. Phillips, R. A., Ma, Z., Kong, B., \& Gao, L. (2020). Maternal Hypertension, Advanced Doppler Haemodynamics and Therapeutic Precision: Principles and Illustrative Cases. Current Hypertension Reports, 22(7), 49. https://doi.org/10.1007/s11906-020-01060-2

24. Prabhakara, G. (2010). Health Statistics (Health Information System). In Short Textbook of Preventive and Social Medicine. https://doi.org/10.5005/jp/books/11257_5

25. Purhadi, Sari, D. N., Aini, Q., \& Irhamah. (2021). Geographically weighted bivariate zero inflated generalized Poisson regression model and its application. Heliyon, 7(7), e07491.

https://doi.org/10.1016/j.heliyon.2021.e074 91

26. Rangkuti, N. A., \& Harahap, M. A. (2020). Hubunga Pengetahuan dan Usia Ibu Hamil dengan Kehamilan Risiko Tinggi di Puskesmas Labuhan Rasoki. Jurnal Education And Development, 8(4), 513.

27. Setiawan, B., \& Nurcahyanto, H. (2020). Analisis Peran Stakeholders dalam Implementasi Kebijakan Penanggulangan Angka Kematian Ibu Studi Kasus Kecamatan Pedurungan Kota Semarang. Journal of Public Policy and Management Review, 9(2), 127-144. 
Milhan et.al. The relationship between age, parity, early detection, K1-K4 visits, integrated ANC, three times Obgyn's ultrasound examination, and maternal mortality.

28. Suarayasa, K. (2020). Strategi Menurunkan Angka Kematian Ibu (AKI) Di Indonesia. Deepublish.

29. Thurber, B. W., \& Fleischer, A. C. (2019). Ultrasound Features of Rudimentary Horn Ectopic Pregnancies. Journal of Ultrasound in Medicine, 38(6), 1643-1647. https://doi.org/10.1002/jum.14847
How to cite this article: Milhan, Indang Trihandini, Shinta Prawitasari. The relationship between age, parity, early detection, K1-K4 visits, integrated ANC, three times Obgyn's ultrasound examination, and maternal mortality. International Journal of Research and Review. 2022; 9(1): 321-327. DOI: https://doi.org/10. 52403/ijrr. 20220138 